\title{
KÓPHÁZA - SZÉLES FÖLDEK, AVAGY AZ ŐSKORTÓL A 2. VILÁGHÁBORÚIG
}

UjVári Ferenc

Magyar Régészet 8. évf. (2019), 3. szám, pp. 20-27, https://doi.org/10.36245/mr.2019.3.5

A Kópháza - Széles földek néven összevont lelöhelyen 2018 májusa óta folytak megelözö ásatások, melyek során több temetö- és településrészlet is elökerült. A nagy kiterjedésü területen több ezer, a rézkortól a modern korig keltezhető jelenséget tártunk fel. A középső bronzkori, Hallstatt, késö vaskori, ill. kora császárkori sírok értékes adalékot nyújtanak a régió történetéhez; a császárkori temetörészlet valószínüleg a germán kvád népességhez kapcsolható.

A győri Rómer Flóris Művészeti és Történeti Múzeum 2018 folyamán megelőző feltárást végzett Kópháza - Széles földek összevont lelöhely területén, az M85-ös gyorsforgalmi autóút Csornától Sopron keleti részéig tartó szakaszának feltárásaihoz kapcsolódóan. Ennek során egy többkorszakú, rendkívül intenzív lelőhely képe rajzolódott ki előttünk - temetők, települések, magányos sírok egyaránt elökerültek. $29489 \mathrm{~m}^{2}$-en több mint 2200 jelenséget kutattunk meg (1. kép).

A Sopron és Kópháza között fekvő lelőhelyen - illetve az összevonást megelőzően az egyes lelöhelyrészeken - 2017 öszén végeztünk próbafeltárást. Ennek során néhány kora és késővaskori sír is

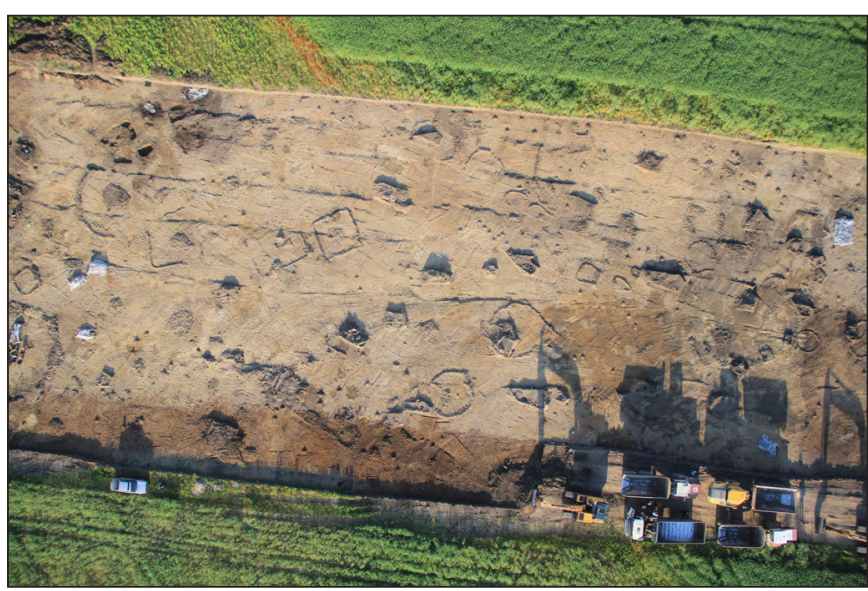

1. kép: A temetörész humuszolás közben (Fotó: Aeroart-Légikép Kft.) feltárásra került, melyek alapján kiterjedt vaskori temető(k)re számítottunk. A megelőző feltárás erősen árnyalta ezt a képet.

A terület humuszolása folyamatos fémkeresőzés mellett folyt, melynek eredményeképpen nagy menynyiségü fémanyagot gyüjtöttünk. Ez a módszer nélkülözhetetlennek bizonyult, mert a hamvasztásos sírok nagy része magasan, a humuszrétegben helyezkedett el ill. kezdődött, az altalajba alig-alig mélyültek le, így fémkeresős gyüjtés nélkül a sírok nagy része a humuszolás során megsemmisült vagy erősen sérült volna. ${ }^{1}$

A lelőhely feltárását 2019 májusában kezdtük meg. Munkánkat több tényező nehezítette: a terület intenzitása, a sóderes-agyagos altalaj, kőpakolás, ill. a feltárás teljes időtartama alatti magas talajvízszint. A mély sírok és egyéb jelenségek bontását nagymértékben akadályozta a vízzel való folyamatos küzdelem; ez különösen a középső bronzkori és a késő vaskori csontvázas sírokra volt igaz.

A nagy kiterjedésü lelőhely egyaránt tartogatott számunkra települést és temetőt is, ráadásul - mint az a bevezetőből már kiderült - több korszakból. A temetők (középső bronzkor, kora vaskor, késő vaskor, római kor) a lelőhely déli részén helyezkednek el, a településrész pedig a temetőtől északra, átfedésben a temetőrész északi részével. A temetkezések esetében a legtöbb korszak használt kőpakolást: mind a középső bronzkori, mind a kora és késő vaskori síroknál előfordult a kőpakolás valamilyen formája. A bronzkori sírok esetében olykor a mély sírgödör teljes szélességében és mélységében köpakolás jelentkezett.

A középső bronzkorra keltezhető sírok a temetőrész déli és középső részén, mindenféle rendszer nélkül, szétszóródva helyezkednek el. Tájolásuk is változatos: értékelhető emberi maradványok hiányában olykor a mellékletek alapján lehet következtetni a test tájolására. Ez alapján a föirány délnyugat-északkelet

A terület fémkeresőzését és humuszolását Horváth Tamás és Scherer Gábor régésztechnikusok végezték. A feltárás munkatársa volt rajtuk kívül Nagy Gábor és Szabados György régésztechnikus. Hatos János, Molnár Dorina és Kovács Pál (Lekri Kft. és Archeodata Kft.) is segítették a feltárást. Munkájukat ezúton is köszönöm! 


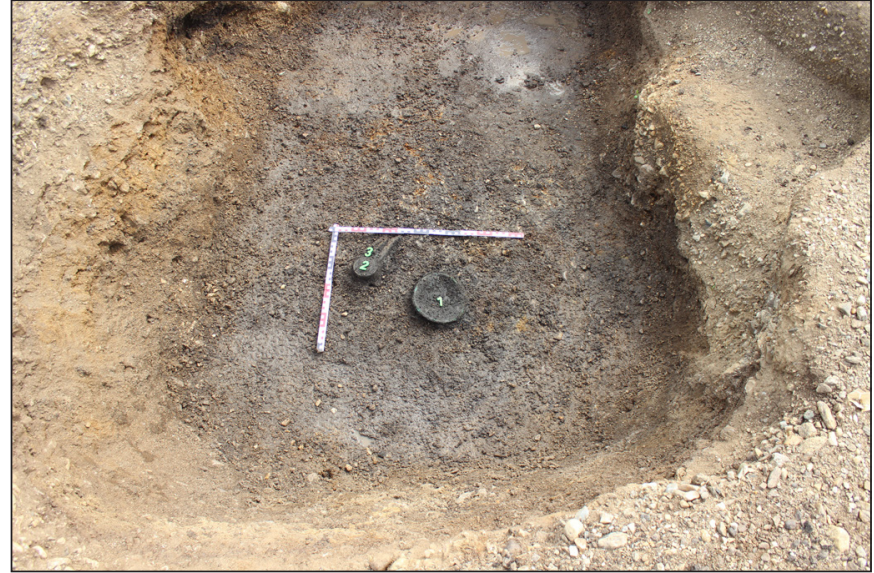

2. kép: A 315. sír mellékletei a sírban lévö egyetlen csonttöredékkel (fotó: Szabados György)

volt, de előfordul ezzel ellentétes tájolás és északdéli irányban tájolt sír is. A sírok csontvázasak, bár legtöbbjükben a megmaradt csontok száma kevés volt, és/vagy rendkívül rossz állapotban voltak (2. kép). Kivételt képez ez alól az S-1175. sír. Az innen előkerült, nem anatómiai rendben feltárt vázcsontok feltehetöleg több egyénhez tartoztak (3. kép). Két hamvasztásos temetkezést is feltételesen ide sorolunk. ${ }^{2}$ Így összesen 7-9 sír tartozik az időszakhoz. A csontvázas sírok vagy mélyek voltak, teljes mélységükben kőpakolással, vagy viszonylag sekélyek, melyekben a kövek bizonyos rendszer szerint voltak elhelyezve (4. kép). Külön kiemelném az S-1625-ös sírt, amely a lelöhelytöl kissé délre, a feltárási területen kívül, régészeti megfigyelés során került elő, közvetlenül a gyökérzóna alól. A téglalap alakú sírgödör épphogy belemélyedt az altalajba, formáját csak bizonytalanul lehetett megfogni. A leletek és az emberi maradványok a sír északnyugati részében egy kupacban kerültek elő: három db, kisebb-nagyobb borostyángyöngy, apró kerámiatöredék, apró bronztöredék és egy négy nittszeges tőr, apró

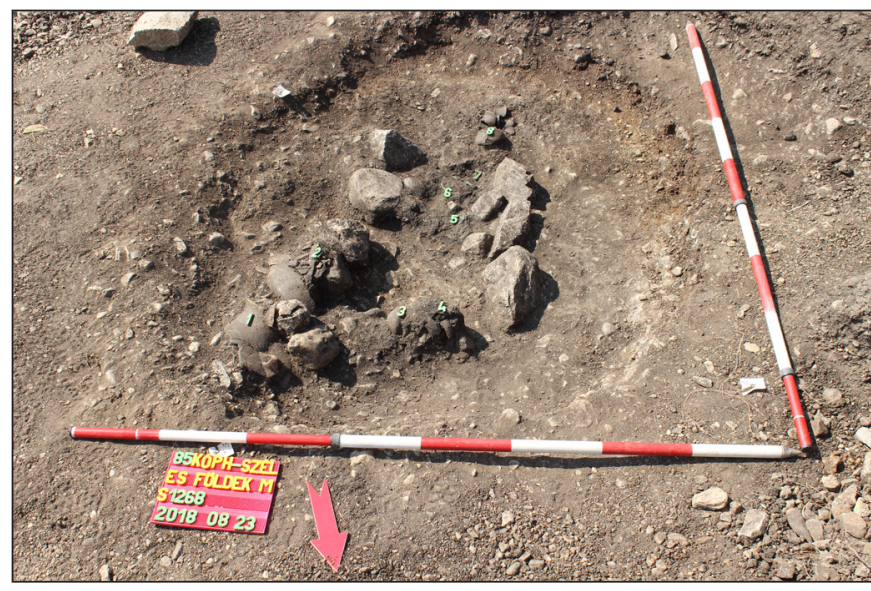

4. kép: Az 1268. sír a kőpakolással, váz maradványával és a mellékletekkel (fotó: Szabados György)

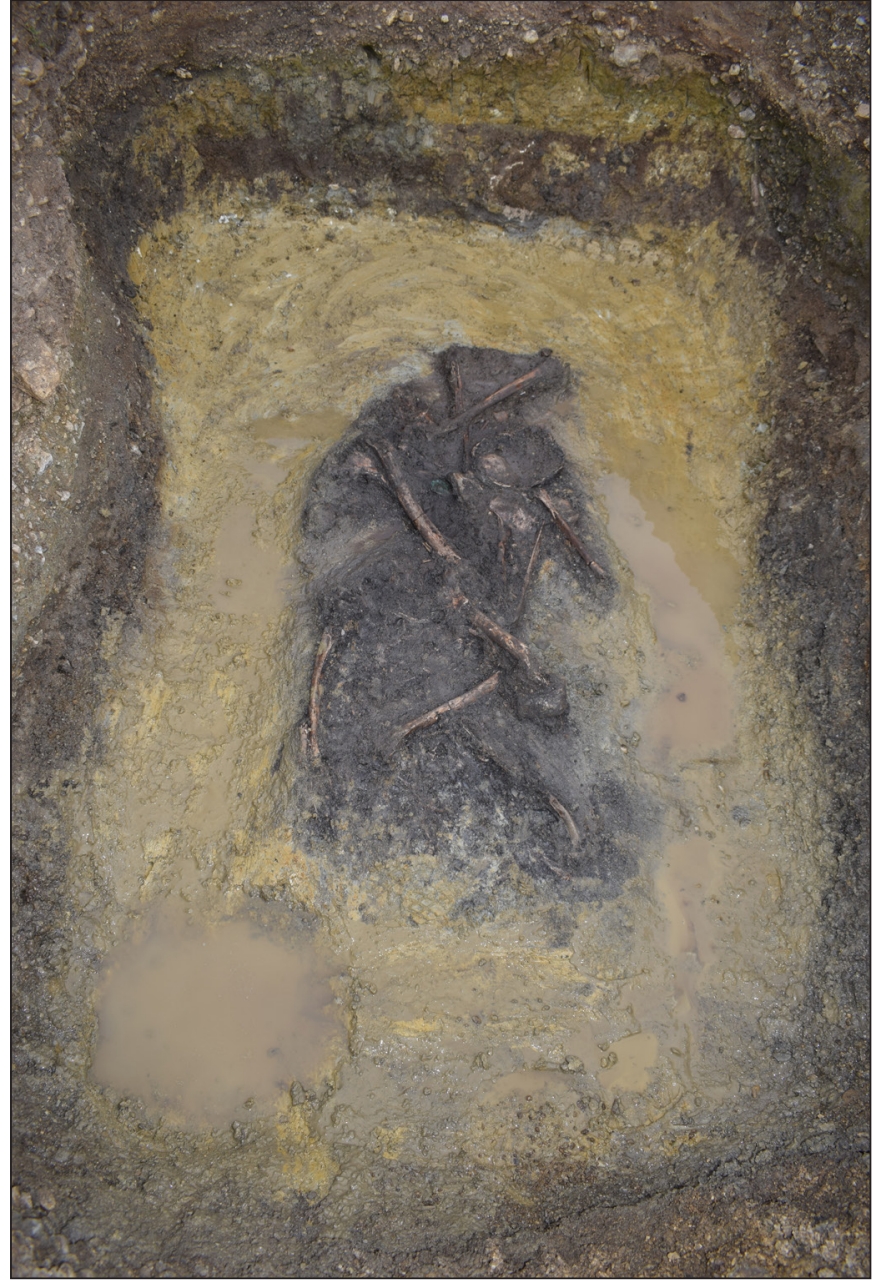

3. kép: Az 1175. sir (fotó: Horvát Tamás)

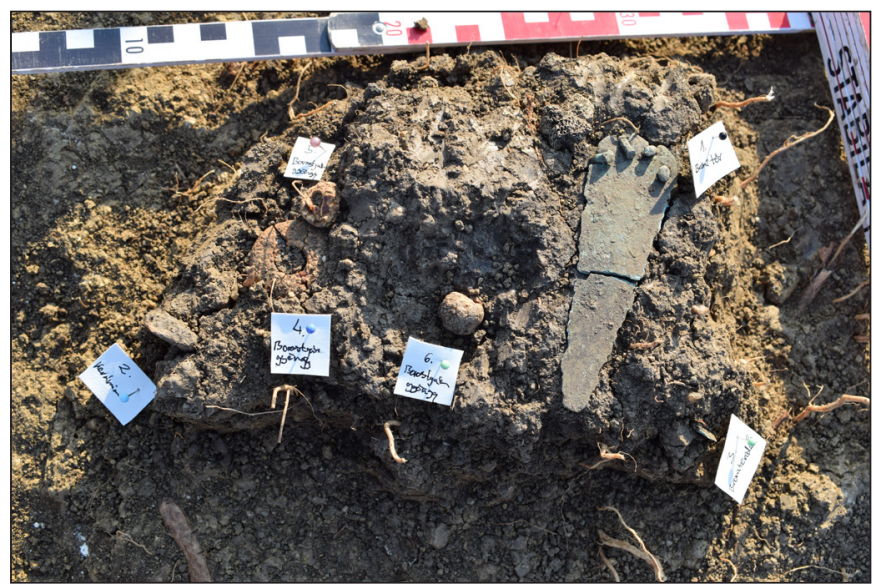

5. kép: Az 1625. sir mellékletei (fotó: Horváth Tamás)

2 A kis méretű sírgödörböl, a hamvakon kívül csupán edénytöredékek kerültek elő. Restaurálásuk után lehet biztosabban datálni és kulturális szempontból besorolni őket. 
Ujvári Ferenc • Kópháza - Széles földek, avagy az öskortól a 2. világháborúig

csonttöredékek társaságában (5. kép). A humuszolás során, a sír közvetlen közeléből egy peremes balta került elö; ezt nagy valószínüséggel szintén a sír mellékletei közé sorolhatjuk.

A fém- és edénymellékletek - torquezek (nyakperecek), kartekercsek, török, hajkarikák - alapján a sírokat a Kr.e. 2100 és 1700/1600 közé keltezhető Gáta-Wieselburg kultúrába sorolhatjuk. ${ }^{3}$ Talán érdemes megjegyezni, hogy hajkarikák kizárólag a sekély sírokban fordultak elö.

A kronológiában következő temető a kora vaskori Hallstatt kultúrához tartozik. A kultúra sírjai a temetőrész déli felén kerültek elö. A kizárólag hamvasztásos sírok közös jellemzője, hogy viszonylag magasan helyezkedtek el, a humuszréteg aljában vagy az altalajba csak kissé mélyülve, továbbá, hogy fémben szegények, edénymellékletekben gazdagok voltak. Sajnálatos módon az edények többnyire rossz állapotban, gyakran összenyomottan kerültek elő.

Összesen 17-22 sírt tártunk fel ebből a korszakból. ${ }^{4}$ A sírban lévő nagyméretü urnák külső felülete gyakran bekarcolt háromszögekkel, cikk-cakk vonalakkal és sraffozott háromszögekkel volt díszítve, olykor grafitozták is őket (6. kép). Aljukban, a hamvakon gyakran találtunk kis méretü tálkát vagy csészét. Az urnákon kívül tálakat, fazekakat, csészéket helyeztek a sírba. Több esetben figyeltünk meg sírszerkezetre utaló cölöplyukakat is: ezek sokszor a sírgödör sarkaiban helyezkedtek el, kiugorva annak síkjából (S-1118, 1155) (7. kép), de előfordultak a sír aljában is (S-1128).

A kora vaskori sírok sorából kiemelkedik az S-1/125-ös és az S-198-as számú sír. Az urnákon kívül mindkettőből jelentős mennyiségü edénymelléklet (több mint 20 edényt) került napvilágra (8. kép). Az S-1/125-ös sír a humuszréteg aljában helyezkedett el, az altalajba épphogy lemélyült; rövid oldalai kőpakolással voltak kirakva. Az edényeken megfigyelhető díszítések nagy része a Kalenderberg kultúra motívumkincséből ismert. Néhány sírt (S-306, 414, 1128) kerítőárok vett körbe.

A feltárási területen kívül, a szelvény nyugati széle mentén helyezkedett el a körárok által határolt

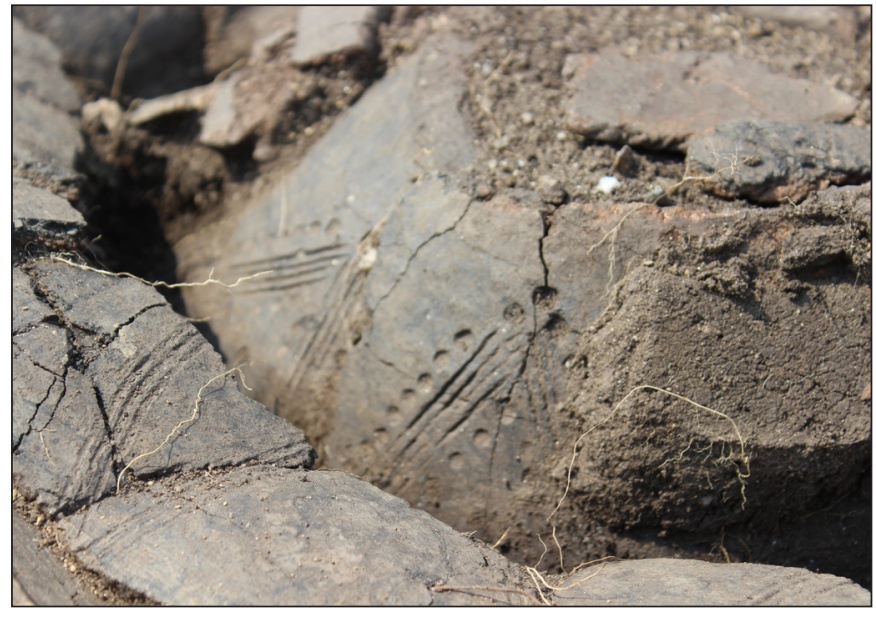

6. kép: Az 1155. sir egyik urnájának díszitése (fotó: Szabados György)

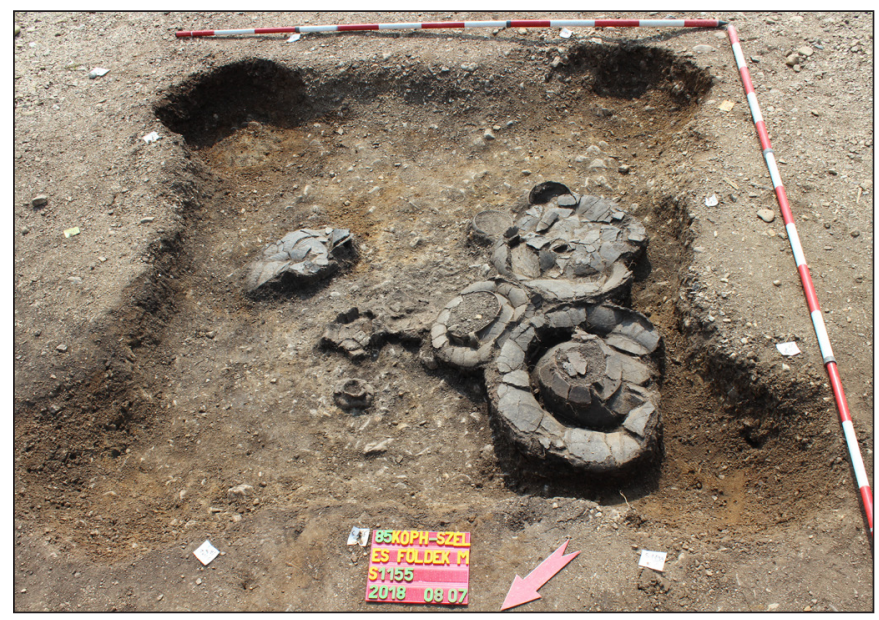

7. kép: Az 1155. sír, sarkaiban cölöplyukakkal (fotó: Szabados György)

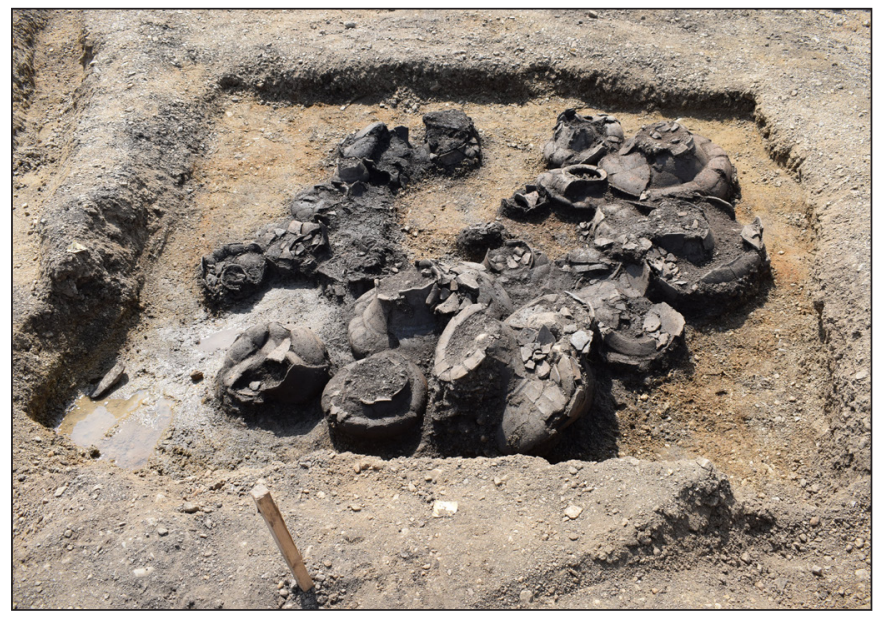

8. kép: A 198. sír (fotó: Szabados György)

\footnotetext{
A Gáta-Wieselburg kultúra hazai kutatása az elmúlt években felfedezett és feltárt lelőhelyeknek köszönhetően új lendületet kapott: pl. Zsennye - Kavicsbánya (NAGY, 2013, pp. 75-173); Nagycenk-Lapos rét (GöMörI et al., 2018, pp. 5-82). Legújabban az M85-ös gyorsforgalmi út építéséhez kapcsolódó próba- és megelőző feltárások során került elő a kultúra egy rendkívül gazdag temetője Nagycenk - Farkasverem lelőhelyen, Mrenka Attila és Savanyú Bálint feltárásán.

4 A bizonytalanság néhány magasan fekvő hamvasztásos sír rossz állapotából és a mellékletek szegényességéből adódik. A restaurálás és feldolgozás után lehet megállapítani a sírok pontos számát.
} 


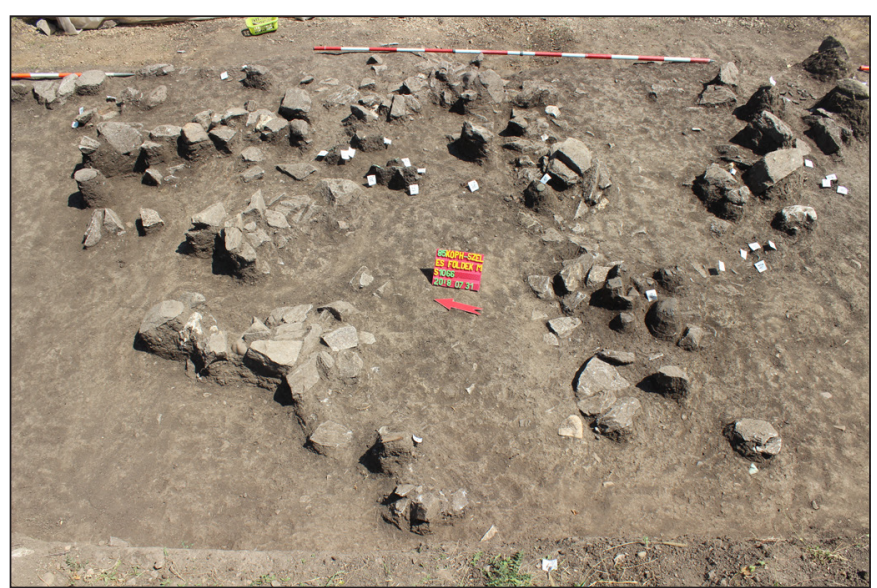

9. kép: Az 1066. jelenség felsö bontási szintje (fotó: Szabados György)

S-1066-os objektum, egy nagy kiterjedésü, nehezen értelmezhető jelenség. Mellékletei és kőpakolása már a jelenlegi járószint alatt, a humuszrétegben jelentkeztek: edénytöredékek, vas- és bronztárgyak, valamint azok töredékei (vaskard töredékei, vaskések, bronzdíszes vaslándzsa, bronzfibulák, nagyméretü, kerek bronzgombok, bronz karperecek, lószerszám (?) vasszerelékei stb.) kerültek elö, rendszertelen kőpakolás társaságában (9-10. kép).

A jelenséget több bontási szinten tártuk fel és dokumentáltuk, mivel a mellékletek és kövek nagy sürüségben helyezkedtek el egymáson. A feltárt mellékletek a kora vaskorra és a kora császárkorra datálhatóak. Emberi maradványok (csontok, hamvak) egyáltalán nem kerültek elő a bontás során. A kőpakolás elemei, és a kora vaskorra és kora császárkorra keltezhető mellékletek rendszertelenül helyezkedtek el a jelenségen belül. Beásás nem volt megfigyelhető. A jelenség legvalószínübb értelmezése, hogy egy kora vaskori sírba, esetleg halomsírba a császárkor folyamán a területre érkező germánok beletemetkeztek, a későbbi talajmüvelés pedig nagymértékben megbolygatta, kimozdította és rongálta a magasan fekvő mellékleteket. Az emberi maradványok hiányára azonban ez sem ad magyarázatot.

A kora vaskori temetőt jelenleg a Ha C/D1 fázisokra tudjuk datálni. A restaurálás és a feldolgozás folyamán ez még bizonyosan finomodni fog.

A késő vaskori temető 20 sírral képviselteti magát. A korszakhoz tartozó temetkezések nagy területen szóródnak, egy déli és egy északi sírcsoport különíthető el. Közös jellemzőjük, hogy erősen raboltak. Némelyik sír teljesen ki volt fosztva, sem csontok, sem mellékletek nem kerültek elő, csupán elhelyezkedése és a kőpakolás szerkezete alapján lehet következtetni késő vaskori voltára: a korszakban többnyire a sírok széleit látták el kőpakolással. Ahol előkerültek csontok, ott is rendkívül rossz állapotban. A temető birituális: egyaránt feltárásra kerültek hamvasztásos és csontvázas sírok, bár a csontvázas sírok dominálnak. A temetkezések döntően délkelet-északnyugati tájolásúak voltak, közülük több - hamvasztásos és csontvázas egyaránt - négyszögletes kerítöárokkal határolt.

A korszakhoz tartozó temetkezések közül kiemelendő az S-235-ös hamvasztásos sír és az azt körülvevő S-236-os kerítőárok. A kis méretű hamvasztásos temetkezés teljes egészében szétdúlt volt, csupán kisebbnagyobb edénytöredékek kerültek elő belöle. Különlegességét az adja, hogy egyrészt mind a sír, mind a kerítőárok kőpakolással volt ellátva, másrészt a sírgödör hosszoldalának felső részén, egymással szemközt, 
Ujvári Ferenc • Kópháza - Széles földek, avagy az öskortól a 2. világháborúig

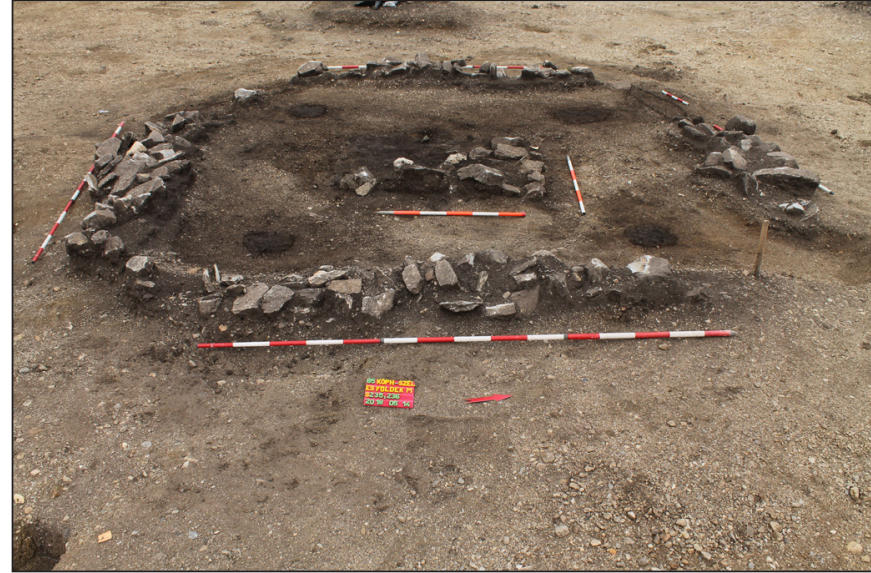

11. kép: A 235. sír és keritöárka bontás közben (fotó: Szabados György)

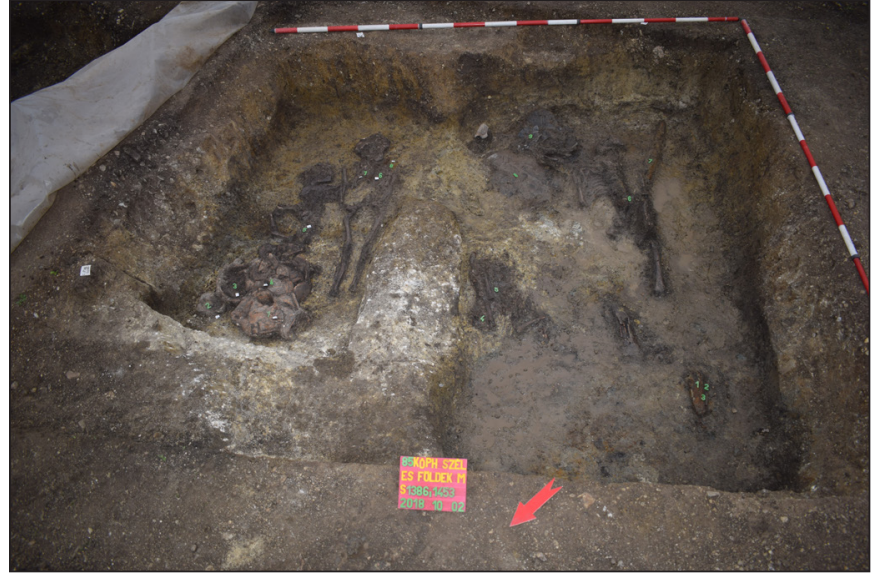

12. kép: Az 1386. és 1453. sir fotó: Horváth Tamás)

valamint a kerítőárok által határolt rész sarkaiban is cölöplyukakat figyeltünk meg, melyek sírépítményre utalnak (11. kép). Megemlítendő még az S-1352, egy férfi és egy női vázat rejtö, szintén erősen szétdúlt, mellékletekkel gazdagon ellátott sír, továbbá a széles és mély kerítőárokkal körülvett térségben jelentkező S-18-as, 1386-os és 1453-as sírok. Közülük a két utóbbi, egy férfi és egy női temetkezés, bolygatatlan volt, edénymellékletekkel, állatcsontokkal, fibulákkal, fegyverekkel (12. kép).

A sírokban előforduló leletek alapján jelenleg a La Tène kultúra korai fázisának második felére keltezzük a temetőt, mely valószínüleg megélte a közép La Tène időszakot is (LT B-C1). ${ }^{5}$

A legnagyobb meglepetést a kora császárkori sírok előkerülése jelentette, főként ilyen magas számban. A megelőző feltárás során összesen 60-64 sír került napvilágra. ${ }^{6}$ Ahogy már említettük, megtalálásuk, megfigyelésük nem volt egyszerü feladat, ugyanis nagyrészük magasan, a humuszszintben jelentkezett, folt nélkül vagy rosszul elváló folttal. A nagy mennyiségü mellékletet tartalmazó sírok bontása és dokumentálása rétegröl-rétegre történt.

A korszakhoz tartozó temetkezések túlnyomórészt hamvasztásosak: ezek többnyire urnás, ritkán szórt hamvas sírok, de néhány csontvázas sírt is ide sorolhatunk. Szinte a teljes temetőrész területén előfordulnak, egyedül a terület északi végén nem kerültek elő. Olykor árkolással vették őket körbe. A sírokban feltárt mellékletek alapján a társadalom széles spektruma jelen van a temetőben: ékszerekben és egyéb mellékletekben gazdag női, fegyverekben és viseleti elemekben gazdag férfi sírok, ill. mellékleteket alig-alig vagy egyáltalán nem tartalmazó urnás és szórt hamvas sírok egyaránt elökerültek. ${ }^{7}$

A gazdag női sírok kiváló példája az S-1308-as hamvasztásos sír. A hamvakat tartalmazó urnában római üvegfiola került elö, az urna mellett egy kupacban bronzfibula, gombok, övveret, gyöngy, olvadt üveg, olvadt bronzedény töredékek, birkanyíró olló, és vastárgyak töredékei voltak (13-14. kép). A gazdag férfisírok az összehajtogatott fegyverek (kard, lándzsa, pajzsdudor) mellett övvereteket, olvadt bronzedény töredékeket, olvadt üvegékszereket rejtettek (15-16. kép).

Egy, a korszakhoz sorolható, különösen gazdag, mellékletei alapján női csontvázas sírt (S-1261) igen mostoha körülmények között tártunk fel, a sír ugyanis mélyen a talajvízszint alatt jelentkezett. Az északnyugat-délkeleti tájolású, háton fekvő, nyújtott váz bal oldala mentén egy bronzserpenyőből, terra sigillata csészéből, vékony falú csészéből és két bordázott üvegtálból álló étkészlet került elő (17. kép). A váz mellett több fibulát is találtunk.

A rabolt sírokból kevés és többnyire igen rossz állapotú fémanyag került elő. A tárgyak restaurálása után pontosabb keltezés várható.

6 Feltárásra kerültek szórt hamvas, ill. kevés és rossz állapotú mellékletet tartalmazó sírok is, melyek datálása és kulturális besorolása éppen ezért bizonytalan, tekintve, hogy más, hamvasztást használó közösség is temetkezett a területre. Pozíciójuknál fogva valószínüsítjük, hogy ez a pár sír is a római korra keltezhető, de biztosat csak a restaurálás és feldolgozás után lehet mondani.

Az urnákba nem bontottunk bele, egyben emeltük ki őket. Bontásukra és dokumentálásukra a restaurátorműhelyben kerül sor. 


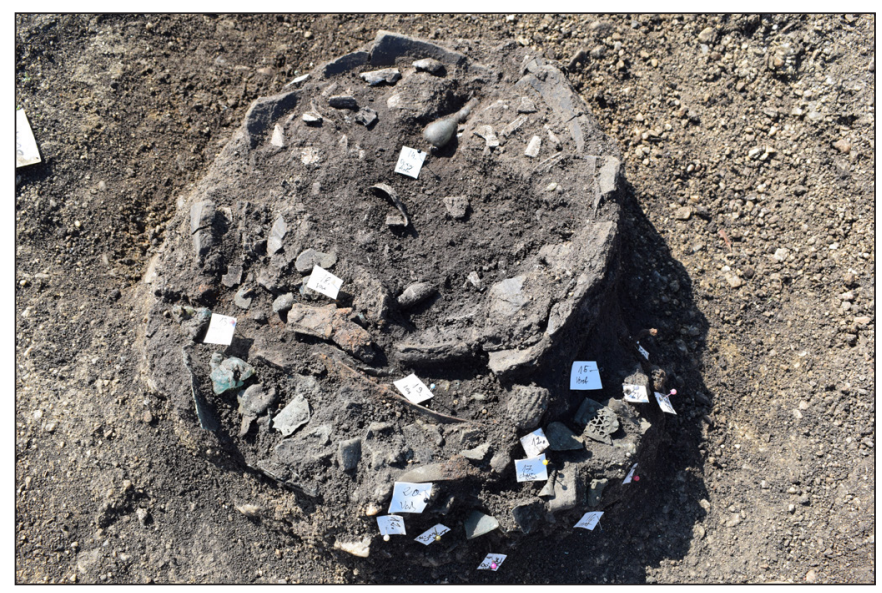

13. kép: Az 1308. sir (fotó: Horváth Tamás)

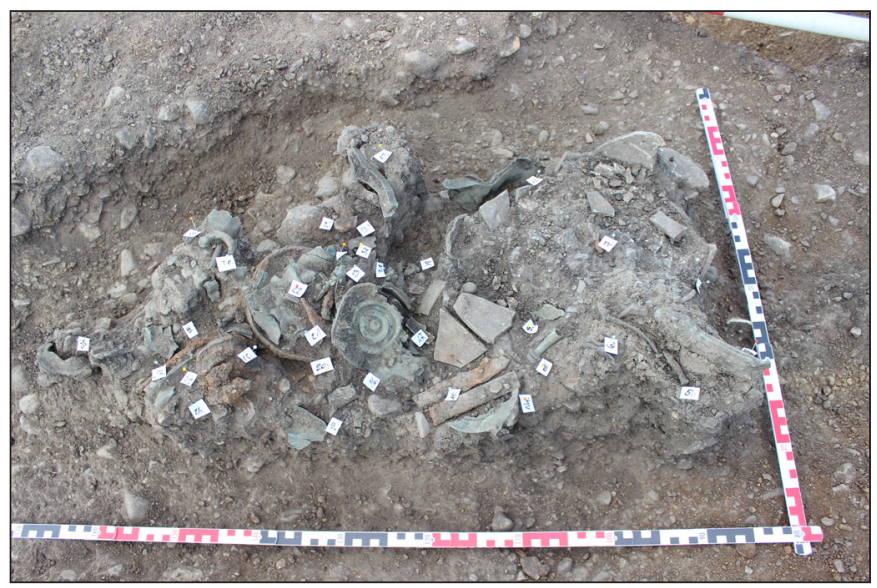

15. kép: Az 1216. gazdag hamvasztásos férfisir (fotó: Horváth Tamás)

A sírokból tehát nagy mennyiségben került elö római leletanyag (fibulák, edények, bronzedények), de germán elemek is szép számban előfordultak (fegyverek, fibulák, edények, övszerelékek, övcsatok), akárcsak a Dunától északra, a Pannonia provincián kívüli, kvád barbarikum területén feltárt temetőkben, mint Ábrahám / Abraham, Egyházfa / Kostolná pri Dunaji, Diószeg / Sládkovičovo (Kolník, 1980), vagy Kisudvarnok / Malé Dvorníky (РroнÁszKa, 2010). A sírokból előkerült mellékletek mind ebbe az irányba mutatnak, ráadásul a fibulák, fémedények és egyéb mellékletek alapján a temető használata is egyidősnek tűnik az említett temetőkével: az 1. század közepére, második felére, ill. a 2. század elejére datálhatjuk (Stufe B1bB2). A számos analógia, a hasonló rítusok és a kronológiai egyezés alapján a kópházi kora császárkori temetőrészletet is a kvádokhoz köthetjük.

Ezzel együtt felvetődik a kérdés, hogy mit keresett egy fegyverrel felszerelt, a sírok tanúsága alapján családdal érkező idegen népcsoport Pannonia provinciában, Scarbantia közvetlen közelében? Talán segédcsapatot alkottak? Ezt talán elvethetjük, mivel, mint említettük, nem csak harcosokról, hanem női és 
Ujvári Ferenc • Kópháza - Széles földek, avagy az öskortól a 2. világháborúig

gyereksírokról is szó van. Kielégítőbb magyarázatnak tünik, hogy egy bukott és elüzött, Róma által befogadott uralkodó kíséretét rejtik a sírok. Erre utalhat a római mellékletek nagy száma: a skyphoszok, paterák, fibulák (erösprofilú, trombita, szemes stb.), fiola, üvegtálak és terra sigillata csésze, hiszen a Pannonia provincia északi határától, a Dunától északra élő kvádok aktív kapcsolatban álltak a rómaiakkal, uralkodó osztályuk folyamatosan római edényekkel, ékszerekkel, élvezeti cikkekkel volt ellátva. Azonban igazán gazdag, nemesfém tárgyakat is tartalmazó sír nem került elő a temetőben.

A mai Délnyugat-Szlovákia területén a Kr. u. 1. század középső harmadában telepedtek meg a germán kvádok. Kr. u. 50-ben ért véget a Kr. u. 18-19 körül Drusus által létrehozott, Regnum Vannianum nevü klienskirályság, Vannius királyt ugyanis szintén Rómához hủ unokaöccsei, Vangio és Sido letaszították a trónról és átvették a helyét, királyságát pedig felosztották egymás között. ${ }^{8}$ Tacitus beszámol róla, hogy Vannius kíséretével együtt Pannonia provincia területére költözött (Annales XII, 2930). Lehetséges, hogy ennek a betelepülő kíséretnek a sírjait sikerült megfigyelnünk? A kérdés eldöntésében a leletanyag feldolgozása fog elörébb vinni. ${ }^{9}$

A temetőkön kívül, azoktól északra különböző korokból származó településjelenségeket találtunk, melyeket a terjedelmi korlátokat figyelembe véve itt csak felsorolás szinten említünk: kora bronzkori, kora vaskori, római kori és Árpád-kori megtelepedés nyomai kerültek elö. ${ }^{10}$ Mindezen felül feltételesen a rézkorral is számolnunk kell két alapárkos épület, pár kőeszköz és néhány kerámiatöredékek alapján. A fémkeresős felderítés során néhány honfoglalás kori fémet is találtunk a lelőhely északi részén. A településrészen egy erősen zsugorított, mellékletek nélküli váz, egy háton fekvő nyújtott váz, továbbá egy második világháborús német katona sírja is napvilágra került. Mindebből láthatjuk, hogy Kópháza - Széles földek lelőhelyen a történelem - és a történelem előtti korok - igazán széles spektruma tárul elénk.

FELHASZnÁlt ÉS AJÁNLOTT IRODALOM

BÓNA, I., 1963.

Beiträge zur Archäologie und Geschichte der Quaden. Acta Archaeologica Academiae Scientiarum Hungaricae 15 (1963), 239-307.

Gömöri, J., Melis, E. \& KIss, V., 2018.

A cemetery of the Gáta-Wieselburg culture at Nagycenk (Western Hungary). Acta Archaeologica Academiae Scientiarum Hungaricae 69 (2018), 5-82.

KolNík, T., 1980.

Römerzeitliche Gräberfeld in der Slowakei vol. 1. Bratislava: Veda - Verlag der Slowakischen Akademie der Wissenschaften.

Mithay, S., 1989.

A Vinár-cseraljai korarómai temető. Frührömische Friedhof in Vinár-Cseralja. Acta Musei Papensis 2 (1989), 49-75.

8 A klienskirályságokhoz és a kvádok történetéhez ld. Prohászka, 2008, pp. 22-46.

9 A kvád temetô jelenléte Sopron mellett meglepő ugyan, de hozzájuk köthető tárgyak már ismertek voltak a Fertö-tó vidékéről és a Lajtavidékről, pl Kismartonból (Eisenstadt) és Mannersdorfból (Bóna, 1963). Hasonló jellegű, talán valamivel később nyitott temető került elő Vinár-Cseralján is (Mithay, 1989).

${ }^{10}$ A kora vaskori település jelenségeiből a Vekerzug kultúrába sorolható tárgytípusok is előkerültek (pl. korongolt, behúzott tálperemek, pecsételő töredéke). Ez, és a településen előkerült egyéb fém- és kerámiatípusok (csónakfibula, szarvasfülű tálak, éles válltörésú tálak stb.) a települést a kora vaskor fiatalabb időszakára (Ha D2-3) keltezik. Úgy tủnik, hogy a Hallstatt település és a temető nem egykorú. 
Ujvári Ferenc • Kópháza - Széles földek, avagy az öskortól a 2. világháborúig

NAGY, M., 2013.

Der südlichste Fundort der Gáta-Wieselburg Kultur in Zsennye-Kavicsbánya / Schottergrube, Komitat Vas, Westungarn. Savaria 36 (2013), 75-173.

ProhászKa, P., 2008.

Imperium et Barbaricum. Kapcsolatrendszerek a Kárpát-medencében a római birodalom és a barbár népek között a római császár- és koranépvándorláskorban. Doktori disszertáció. Budapest, ELTE.

ProhászKa, P., 2010.

Észrevételek a Csallóköz római kori történetéhez avagy új adatok egy feledésbe merült kvád temetőről. Folia Archaeologica 54 (2010), 205-242.

SzABÓ, M., 2005.

Keleti kelták. Budapest: L'Harmattan. 